Article

\title{
Identification of Lithol Red Synthetic Organic Pigment Reveals the Cause of Paint Layer Degradation on the Lazar Vozarević Painting "Untitled" with Copper Plates
}

\author{
Vanja Jovanović ${ }^{1,+}$, Suzana Erić ${ }^{2,+}$, Philippe Colomban ${ }^{3,+}(\mathbb{D}$ and Aleksandar Kremenović $2, *,+$ (D) \\ 1 Tehnoart Beograd, Svetog Nikole 39, 11000 Belgrade, Serbia \\ 2 Faculty of Mining and Geology, University of Belgrade, Đušina 7, 11000 Belgrade, Serbia \\ 3 Sorbonne Université, MONARIS (From the Molecule to the Nano-object: Reactivity, Interaction \& \\ Spectroscopies), UMR8233 CNRS, 4 Place Jussieu, 75005 Paris, France \\ * Correspondence: akremenovic@rgf.bg.ac.rs \\ + These authors contributed equally to this work.
}

Received: 1 August 2019; Accepted: 31 August 2019; Published: 4 September 2019

\begin{abstract}
Out of a total of 56 paintings in the collection of the Lazar Vozarević Gallery in Sremska Mitrovica, only one Lazar Vozarević painting from 1961, titled "Untitled", has been subject to atypical degradation that has resulted in damage of completely atypical appearance. Such a problem had never before been noticed in Yugoslavian paintings of the 20th century. Discolored areas were found in various locations on the paint layer of the painting "Untitled" (especially on the lower and central parts of the painting), which disturbed the visual experience of the artistic work. To discover the cause of this discoloration, the composition of the paint layer was investigated, with the assumption that the true cause of degradation was hidden therein. Moreover, this painting belongs to a specific period in Vozarević's activity, characterized by the use of non-traditional painting materials. To identify pigments from the highly degraded painting "Untitled", scanning electron microscopy coupled with energy dispersive X-ray spectrometry (SEM/EDS) and micro-Raman spectroscopy were applied. Lithol red, a synthetic organic pigment known to give paintings a red tone, was identified as the main reason for the painting's degradation. Lithol red is not only highly light-sensitive but is also chemically unstable, toxic, and sensitive to heat.
\end{abstract}

Keywords: synthetic organic pigment; Lithol red; modern art painting; Raman spectra

\section{Introduction}

Nowadays, micro-Raman spectroscopy is well-known as an effective tool for identifying the molecular structures of different compounds present in artwork [1-5]. A large variety of inorganic and organic pigment materials have previously been identified by micro-Raman spectroscopy [6-14]. In fact, Fremout and Saverwyns [15] reported a comprehensive digital Raman database of 270 synthetic organic pigments (SOP), Vandenabelle, Edwards, and Moens [1] analyzed 21 azo pigments, and Ropret, Centeno, and Bukovec [11] investigated the Raman reference spectra of 21 yellow SOPs, while Scherrer et al. [12] reported a Raman spectral library of 93 SOPs. Furthermore, specific studies regarding Modern Art paintings have been conducted for the works of Francis Picabia [9], Pablo Picasso and Jasper Johns [10]. Scanning electron microscopy coupled with energy dispersive X-ray spectrometry (SEM/EDS) could be useful for obtaining complementary information about the raw materials used in the artifacts $[16,17]$. 
This paper presents a micro-Raman study completed with SEM/EDS measurements of the pigment and ground materials used by Lazar Vozarević in his painting "Untitled" (1961). Bearing in mind the severe degree of paint layer deterioration of the "Untitled" painting, the aim of this research was to determine which materials Vozarević introduced when working on the painting "Untitled" in terms of discovering the causes of these atypical damages. The obtained results are important for conservation treatment decisions as well as for the creation of microclimate conditions that would prevent or at least slow down the degradation process. Also, the insight into the technological characteristics of the "Art Informel" phase in the paintings of one of the most important representatives of Yugoslav modern art.

\section{Painter and the Paintings}

Lazar Vozarević was born on 15 July 1925 in Sremska Mitrovica (Serbia). His works are exhibited in the Art Gallery "Lazar Vozarević" in his hometown, which opened after his sudden death from blood poisoning in 1968, as well as in the Museum of Contemporary Art in Belgrade (Serbia), Art Gallery in Cetinje (Montenegro), and some significant private collections in David Rockefeller (USA), Guido Trevisan (Italy), Villa Lobos (Brazil), Philip Baudet (France), and Paul Flockerman (USA).

Around 1960, a significant change in Vozarević's technique took place when he started transposing medieval icons, ideas, and techniques in the context of the modernist painting concept [18]. According to Lazar Trifunovic in 1960, Vozarević conducted a series of experiments, technology analyses, preparations, and drawings [19] and started a new approach and new ways of creating paintings involving new materials [20].

The following year, Vozarević's new paintings of pure "Art Informel", considered as the best of Vozarević's paintings, appeared at the First Triennial Exhibition [18]. His "Art Informel" was based on experiments with materials, fire and acids, burning material on the paintings, and adding non-painting materials (copper plates $^{1}$, wire, nails, stones, sand, etc.) [19].

\section{Materials and Methods}

\subsection{Sampling}

Five samples were selected for analysis, as depicted in Figure 1 and summarized in Table 1. Large samples, a few millimeters in size, were taken from the edges and corners of the painting and from the damaged areas. However, to respect conservation ethics and avoid damage to the original features of the painting, it was not possible to provide samples from the copper plates and covering layer.

1 It should be noted that painting on copper is an old technique that was mastered in Italy and the Low Countries during the 16 th century. 
Table 1. Selected samples, corresponding photomicrographs and colours, applied methods Raman (including image for Raman analysis) and SEM/EDS and found compositions for painting "Untitled".

\begin{tabular}{|c|c|c|c|c|c|c|}
\hline The Sample \# & Photomicrograph & The Color & $\begin{array}{l}\text { Image for Raman } \\
\text { Analysis }\end{array}$ & RamanAnalysis & SEM/EDS Analysis & $\begin{array}{c}\text { the Suggested Composition } \\
\text { of the Sample }\end{array}$ \\
\hline 1 & & white and black & & $\mathrm{ZnO}$, carbon black & $\begin{array}{l}\mathrm{BaSO}_{4}, \mathrm{ZnO}, \\
\text { Mg-silicate }\end{array}$ & $\begin{array}{c}\mathrm{BaSO}_{4}, \mathrm{ZnO} \text {, carbon black, } \\
\text { Mg-silicate }\end{array}$ \\
\hline 2 & & white & o & $\mathrm{CaCO}_{3}, \mathrm{BaSO}_{4}$ & $\mathrm{BaSO}_{4}, \mathrm{ZnO}$ & $\mathrm{CaCO}_{3}, \mathrm{BaSO}_{4}, \mathrm{ZnO}$ \\
\hline 3 & & red and black & 4 & Lithol red, $\mathrm{BaSO}_{4}$ & $\begin{array}{c}\text { organic material, } \\
\mathrm{BaSO}_{4}\end{array}$ & Lithol red, $\mathrm{BaSO}_{4}$ \\
\hline
\end{tabular}


Table 1. Cont.

\begin{tabular}{|c|c|c|c|c|c|c|}
\hline The Sample \# & Photomicrograph & The Color & $\begin{array}{l}\text { Image for Raman } \\
\text { Analysis }\end{array}$ & RamanAnalysis & SEM/EDS Analysis & $\begin{array}{c}\text { the Suggested Composition } \\
\text { of the Sample }\end{array}$ \\
\hline 4 & & red, black and white & & $\mathrm{BaSO}_{4}$, carbon black & $\begin{array}{l}\text { organic material, } \\
\qquad \mathrm{BaSO}_{4}\end{array}$ & $\mathrm{BaSO}_{4}$, carbon black \\
\hline 5 & & $\begin{array}{l}\text { light brownish red and } \\
\text { black }\end{array}$ & & $\begin{array}{l}\mathrm{Fe}_{2} \mathrm{O}_{3} \text {, Goethite, } \\
\mathrm{BaSO}_{4} \text {, Lithol red }\end{array}$ & $\begin{array}{l}\text { Fe-oxide/ hydroxide, } \\
\mathrm{CaCO}_{3}, \mathrm{BaSO}_{4}\end{array}$ & $\begin{array}{c}\mathrm{Fe}_{2} \mathrm{O}_{3}, \text { Goethite, } \mathrm{CaCO}_{3}, \\
\mathrm{BaSO}_{4} \text {, Lithol red }\end{array}$ \\
\hline
\end{tabular}




\subsection{Methods}

A high sensitivity multichannel notch-filtered INFINITY spectrograph (Jobin-Yvon-Horiba SAS, Longjumeau, France) equipped with a Peltier cooled CCD matrix detector was used to record Raman spectra between $\sim 150$ and $2000 \mathrm{~cm}^{-1}$, using 532 and $632 \mathrm{~nm}$ excited lines (YAG and He-Ne lasers). Backscattering illumination and collection of the scattered light were carried out using an Olympus confocal microscope (long focus Olympus $\times 50$ objective, total magnification $\times 500$ ).
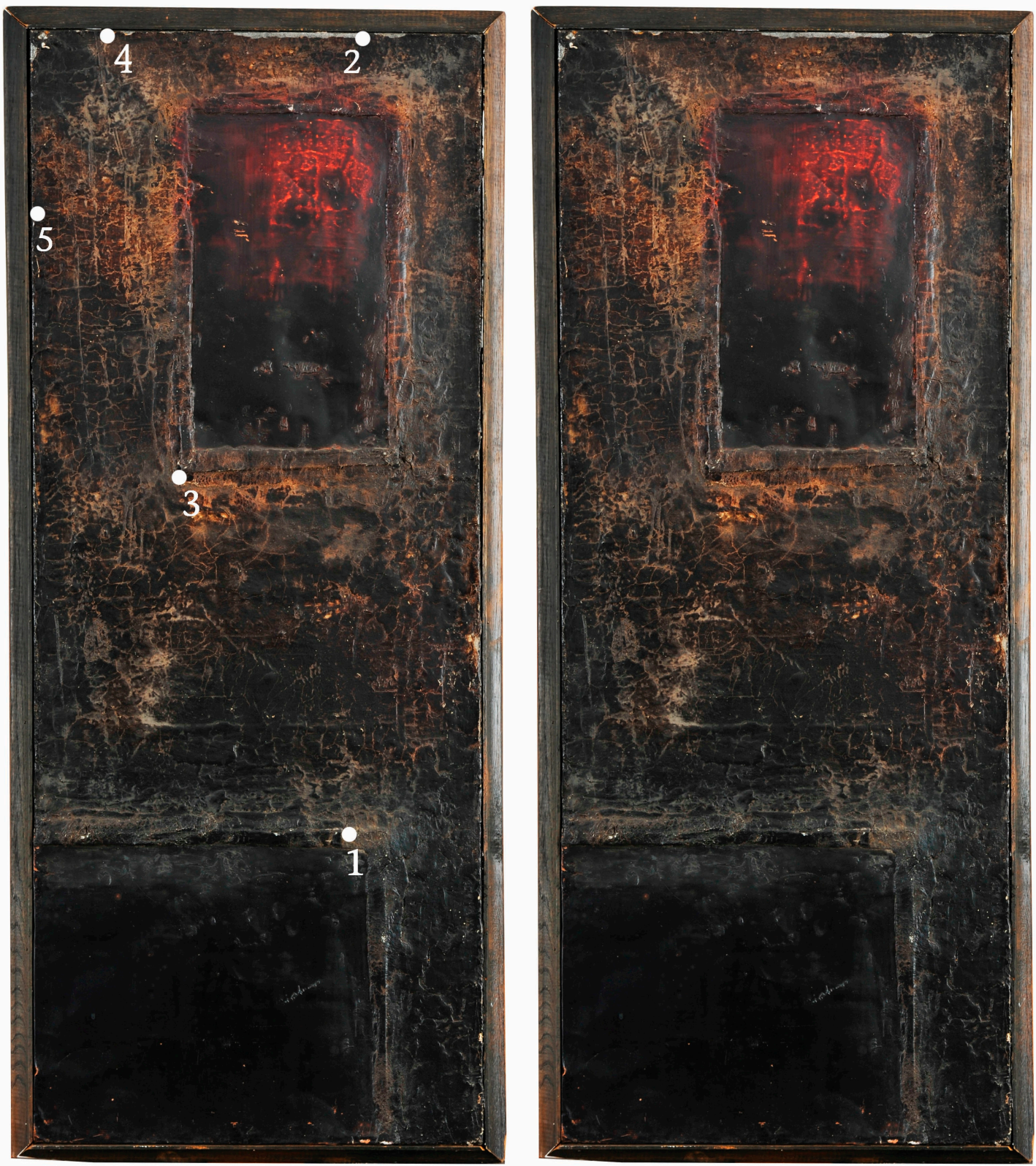

Figure 1. The painting "Untitled" from the Lazar Vozarević Gallery, on canvas support, consists of two copper plates $(37 \times 33 \mathrm{~cm}$ and $37 \times 22 \mathrm{~cm})$ that were tinted with a dark thin coat before $(\mathbf{l e f t})$ and after (right) conservation and restoration treatment. Sampled locations are marked by numbers $1-5$. Matte, blurry, and opaque areas with imprecise edges are degraded.

Strong fluorescence was noticed with both lasers and was minimal for red excitation. The matter of the painting presents some characteristics that are detrimental for the efficiency of optical spectroscopy, namely its dark, corrugated, and porous features. For these reasons, after some preliminary 
measurements showing fast degradation of the spectrum under power levels higher than $1 \mathrm{~mW}$ with a $\times 50$ objective, it was observed that the best spectra, with minimal fluorescence, were obtained at a low power of illumination, 0.05 to $0.1 \mathrm{~mW}$. Three accumulations were made in order to eliminate eventual cosmic ray peaks. The counting times ranged between 15 and 60 minutes, with longer times leading to a decrease in the quality of the spectra. Convenient examination spots were inspected by carrying out examinations on small particle aggregates in order to minimize localized heating. The spectral resolution was $\pm 2 \mathrm{~cm}^{-1}$. Small wavenumber shifts may arise from differences in heat transfer between the illumined spot and the environment. As such, a linear baseline was subtracted.

The Discovery DX-1 USB Microscope (Veho, Southampton, UK)was used for the production of optical photomicrographs.

The morphology and chemical composition of selected samples were identified using a JEOL JSM-6610LV Scanning Electron Microscope connected to an X-Max Energy Dispersive Spectrometer. The samples were set on carbon tape and covered with gold using a BALTEC-SCD-005 Sputter coating device. The results were recorded under high vacuum conditions, an acceleration voltage of $20 \mathrm{kV}$, and a working distance of $10 \mathrm{~mm}$. Appropriate internal standards were used for the chemical analyses. Detection limits for most elements were $0.1 \%$.

\section{Results and Discussion}

Selected specimens of the painting "Untitled" were collected and analyzed by Raman spectroscopy spot by spot on preferably monochrome areas. Representative Raman spectra recorded from the selected samples are shown in Figure 2, Figure 3, Figure 4, Figures S1 and S2. Assignments are listed in Table S1 [32-45]. Raman spectra assigned to Lithol red (PR 49:1) SOP, presented in Figures 2 and 4, fit very well with the reference spectra reported by Vandenabeele et al. [21] and presented in the KIK IRPA database [22]. Small wavenumber shifts may arise from differences in heat transfer between the illumined spots and the environment as well as due to different laser lines $(632 \mathrm{~nm}$ in our experiment and $785 \mathrm{~nm}$ for the data reported in the KIK IRPA database). Groups belonging to $\mathrm{SO}_{3}$ show a weak band at ca. $1170 \mathrm{~cm}^{-1}$, due to the symmetric $\mathrm{SO}_{2}$ stretch. A band at ca. $725 \mathrm{~cm}^{-1}$ can be ascribed to the presence of a naphthalene group in the molecule. The bands at ca. $1603 \mathrm{~cm}^{-1}$ correspond to a benzene quadrant stretch. A peak at $602 \mathrm{~cm}^{-1}$ is also present as a result of aromatic ring deformations. In the literature, there is clear evidence of Lithol red fading due to sunlight [23]. Having this in mind, careful attention was paid to the Raman spectra collection of Lithol red, especially to the used power of illumination.
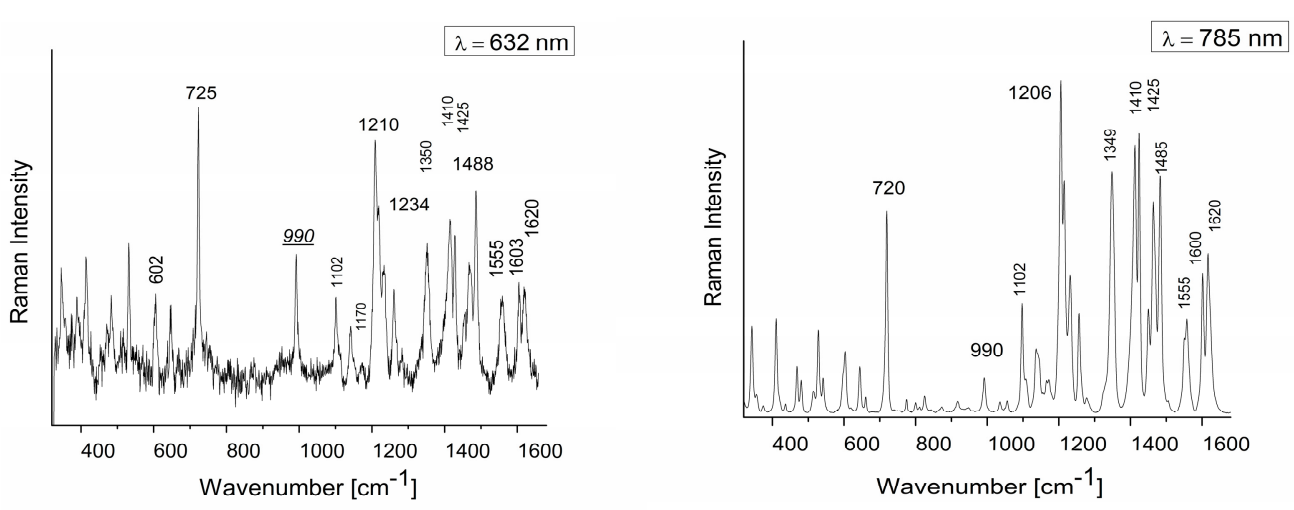

Figure 2. Representative Raman spectra of Lithol red and $\mathrm{BaSO}_{4}$ mixture from the painting "Untitled" recorded on sample 3 (left) and from the KIK IRPA database (right). Different laser lines were used for the spectra record: $632 \mathrm{~nm}$ in this work and $785 \mathrm{~nm}$ for the KIK IRPA database. 


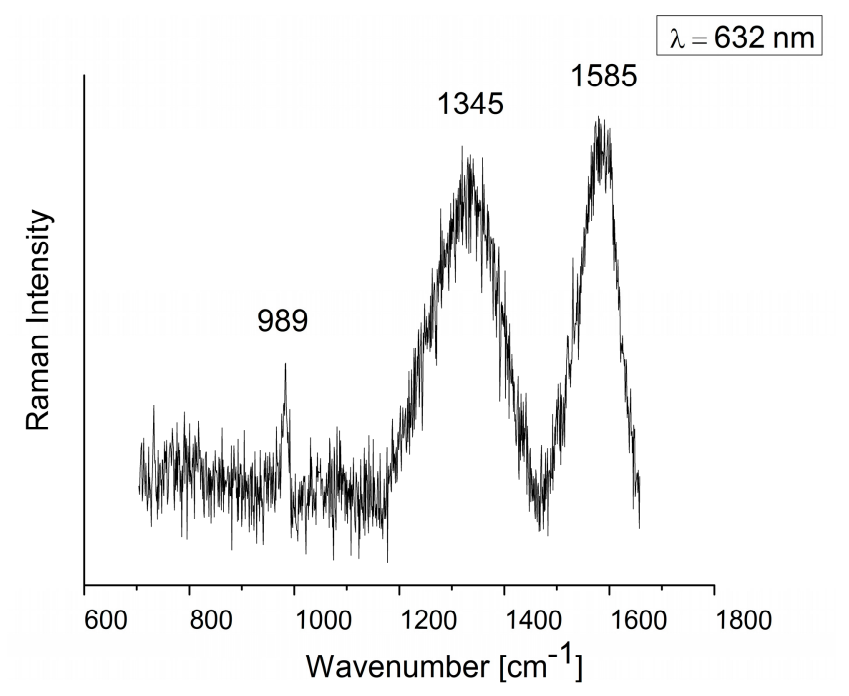

Figure 3. Raman spectra of the grey component of sample 4 for the painting "Untitled" under $632 \mathrm{~nm}$ excitation. The band at ca. $989 \mathrm{~cm}^{-1}$ belongs to $\mathrm{BaSO}_{4}$. Bands at about 1345 and $1585 \mathrm{~cm}^{-1}$ are ascribed to carbon black.
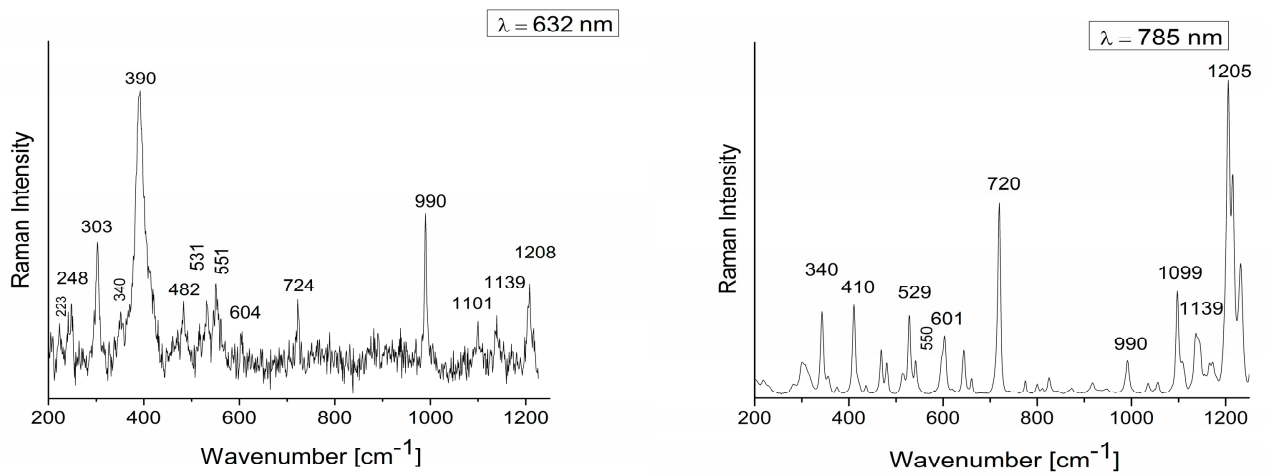

Figure 4. Representative Raman spectra of a Lithol red, $\alpha-\mathrm{FeOOH}, \mathrm{Fe}_{2} \mathrm{O}_{3}$, and $\mathrm{BaSO}_{4}$ mixture from the painting "Untitled", recorded from sample 5. The vibration at approximately $223 \mathrm{~cm}^{-1}$ corresponds to $\mathrm{Fe}_{2} \mathrm{O}_{3}$. Vibrations at about 248, 303, 390, 482 and $551 \mathrm{~cm}^{-1}$ correspond to $\alpha$-FeOOH goethite. The vibration at approximately $990 \mathrm{~cm}^{-1}$ belongs to $\mathrm{BaSO}_{4}$. Vibrations at about 340, 531, 724, 1101, 1139 and $1208 \mathrm{~cm}^{-1}$ belongs to Lithol red (left) and from KIK IRPA database (right). Different laser lines were used for the spectra record; $632 \mathrm{~nm}$ in this work and $785 \mathrm{~nm}$ for the KIK IRPA database.

SEM/EDS results are summarized in Figures 5 and 6 and Table 1. Coarse, angular grains of barium sulphate (barite) with a maximal size of approximately $40 \mu \mathrm{m}$ can be observed in sample one (Figure 5a). In addition to barite, a homogeneous layer of zinc oxide in the same sample can also be observed (Figure 5b). The cross-section of sample two clearly shows several layers with different dominant phases (in dark zones- $\mathrm{ZnO}$, in bright zones-barite) as well as layers in which these two phases are intensely mixed whereby coarse grains of barite stand out (Figure 5c,d). The SEM/EDS analysis of sample three indicated the presence of mostly long organic fibers with a maximum width of up to about $50 \mu \mathrm{m}$ (Figure 5e). Organic fibers and barite were also present in sample four (Figures $5 f$ and $6 a)$, whereas Fe-oxides/hydroxides and calcium carbonate (calcite) were dominant phases in sample six (Figure 6b). 

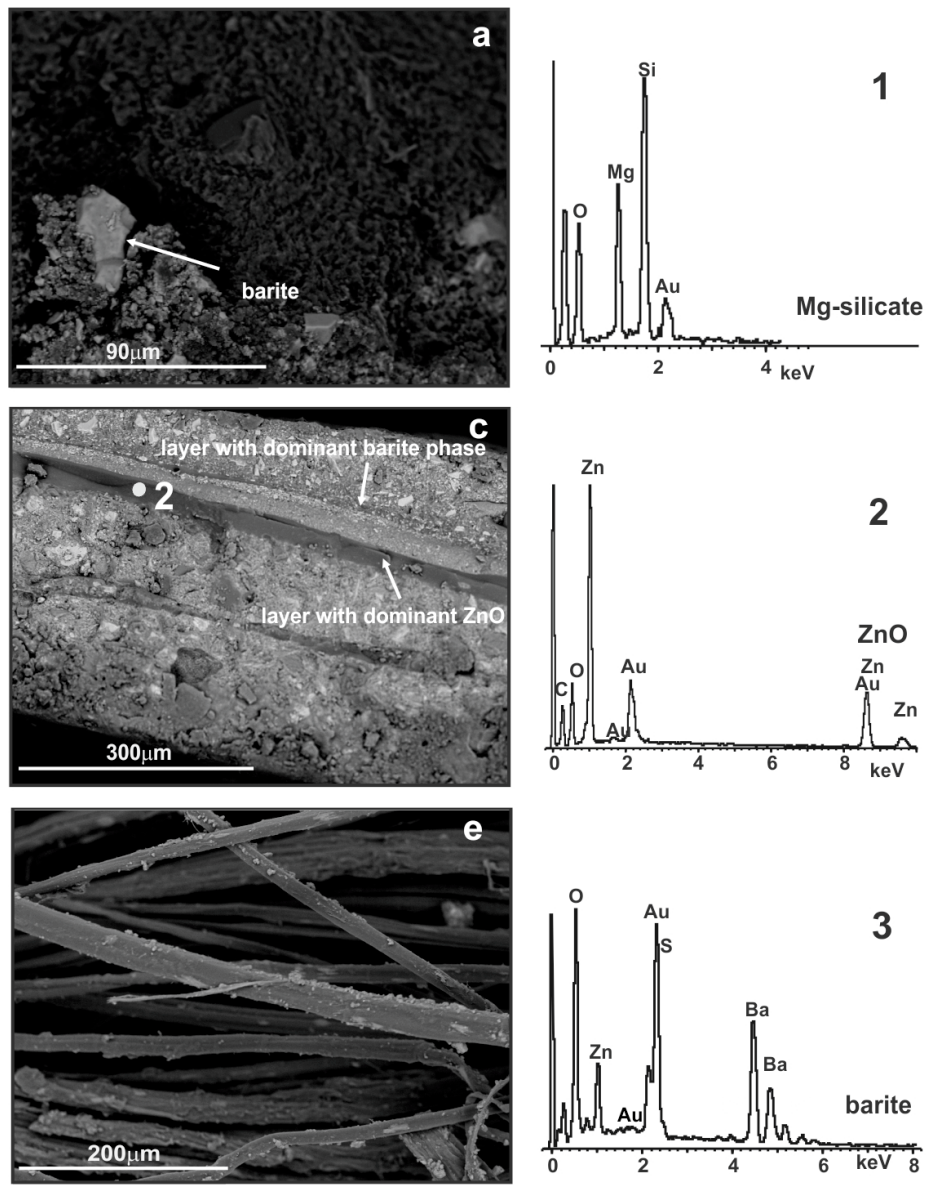
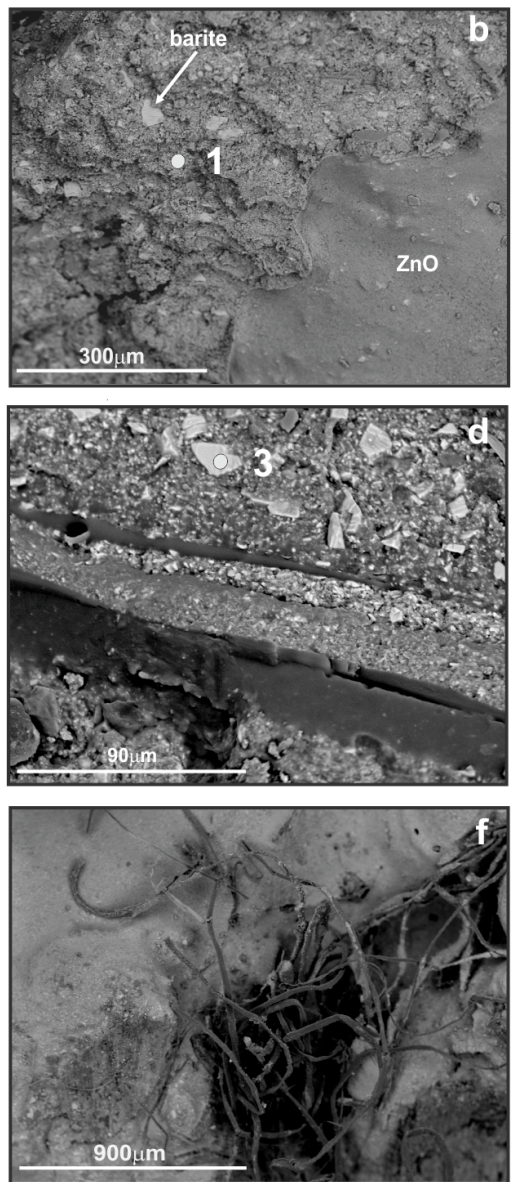

Figure 5. Scanning electron microscopy (SEM) and energy dispersive X-ray spectrometry (EDS) results for the painting "Untitled": (a,b) sample 1; (c,d) sample 2; (e) sample 3; (f) sample 4.
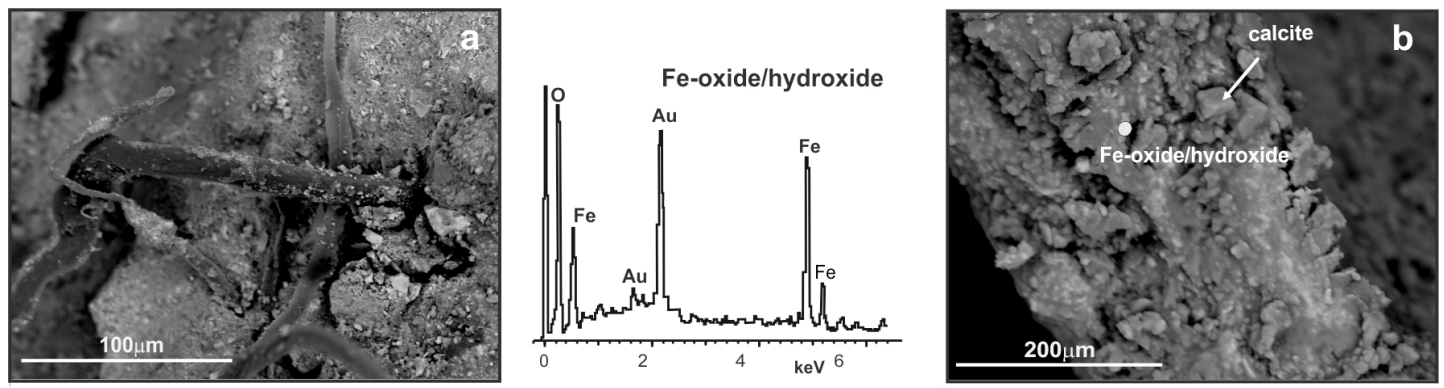

Figure 6. Scanning electron microscopy (SEM) and energy dispersive X-ray spectrometry (EDS) results for the painting "Untitled": (a) sample 4; (b) sample 5.

Evidently, micro Raman spectroscopy and SEM/EDS are useful for the identification of pigments and ground materials of the painting. However, only by micro Raman spectroscopy was it possible to identify Lithol red; due to poor scattering power of light elements, Lithol red was not identified by SEM/EDS.

\section{Conservation and Restoration Treatment}

The conservation history of the painting prior to the foundation of the Gallery is unknown. However, the building in which the painting was stored and exhibited was a repurposed structure [24] before reconstruction concluded in 2017, sharing typical conservation conditions with other gallery and museum buildings built in the first half of the twentieth century. Being unmaintained and without air 
conditioning - with visible damage to the structure and traces of humidity influx, lack of insulation, and often large window areas-these buildings are characterized by sudden, drastic changes in temperature and relative humidity (especially in the exhibition spaces), which causes damage to paintings and results in cracking. In addition, during work on the Lazar Vozarević Gallery, the collection was stored in documented inadequate conditions, the paintings were piled up, and the space was exposed to a daily rise in temperature due to the presence of two windows exposed the east [25].

However, the existing damage on the painting is obviously not just a consequence of micro-climatic conditions and, instead, seems to be the result of the techniques and materials that were used in the case of the painting "Untitled". This is supported by the fact that the remaining 55 paintings, which are part of the same collection and are kept under the same conditions as the "Untitled" painting, do not present changes detected in/on the painted layer.

Our analysis confirms the existence of highly light-sensitive, chemically unstable, and heat-sensitive pigments, such as Lithol red, that made the painting "Untitled" specifically susceptible to environmental conditions and mechanical damage at the level of the paint layer, including the following: disintegration of the adhesive, weakening of the connections between different materials during the aging process, and cracking of thick layers of different origins, etc. [23].

Consequently, the cleaning process had to be minimal and noninvasive, and cleaning of the painting was limited to only the upper layer of the painting surface. Otherwise, using classical cleaning solutions might have initiated further/new degradation processes of the constituting pigments, resulting in irreversible damage to the areas of degradation. Retouching was performed with watercolor paints and completed with pigments with ketone-based resin and selected hydrocarbon solvents ${ }^{1}$, with retouching varnish ${ }^{2}$ between them [26]. Both retouching techniques were done in tratteggio-vertical lines of different colors. Degraded areas on the surface of the paint layer were not retouched to avoid compromising the integrity of the original painting layer.

Considering the underlying causes and extent of deterioration of the painting "Untitled", which would require exhaustive treatment to complete restoration with similar materials and techniques, it was considered to be too invasive and hazardous. Some of the materials on the painting are toxic (e.g., Lithol red, especially in combination with a varnish or an adhesive [27]). Toxic effects of painting components on many modern art paintings are still under, or could be subject to further, investigation. For example, in an extensive, well-documented, and rather expensive project that deals with the restoration of Mark Rothko paintings by a team of leading conservation scientists and scholars at Harvard (see, e.g., Christies site http://www.christies.com/features/Rothko-5014-1.aspx), information about the toxic effects of painting components is lacking. It should be noted that Mark Rothko extensively used Lithol red as well $[23,28] .^{2}, 3$

Additionally, it is evident that after conservation and restoration, color fading is still quite visible (see Figure 1). An alternative method was proposed to virtually restore the pristine state of the painting, concealing the damage of the painted layer without physical intervention to the painting itself [28-30]. This would consist of creating a compensative color pattern which would match the painting's damage and which would be projected on the painting to disguise the damage, effectively creating an optical illusion that the painting has been restored. Following the creation of an exact digital copy of the painting based on spatial, geometry, and color data from the real world, it would be possible to create a virtual retouch and project it on the painting [31].

1 It should be noted that painting on copper is an old technique that was mastered in Italy and the Low Countries during the 16th century.

MAIMERI ${ }^{\circledR}$ Restauro colours.

MAIMERI ${ }^{\circledR}$ Restauro colours.

3 J.G. VIBERT retouching varnish (LEFRANC \& BOURGEOIS) with acrylic and ketone resin quick drying petroleum. Contain the most resin with $25 \%$ dry extract after drying. 
The Lithol red recognition on the painting "Untitled" obtained through the physicochemical analysis presented in this paper would enable precise corrections of degraded colored textures with chromatic changes in tonality and intensity, especially in degraded areas, and accurate virtual restoration and reconstruction of the veritable original look.

\section{Conclusions}

This paper explains the importance of the identification of pigments in a very degraded painting with copper plates, "Untitled" (1961), in the context of: making adequate decisions about the conservation and restoration treatment, creating parameters of the environment that will allow the painting's preservation in the future, as well as restoring the visual value of the work and the original artist's idea through applying a virtual retouch. With this multidisciplinary approach and application of analytical instrumentation, a significant national project of analysis, the conservation and presentation of Lazar Vozarević's artworks, an integral part of the collection of the Gallery Lazar Vozarević, will be completed. It was shown that correlating the results of the used analytical methods allows rather reliable identification of certain pigments, thus distinguishing Lithol red as a pigment exclusively present amongst the components of the "Untitled" painting. The results of the study contribute to the understanding of the causes of extensive mechanical damage to the paint layer of "Untitled", confirming the use of Lithol red and its properties as one of the main factors for the painting's deterioration.

In the last decade, an increasing number of significant easel paintings in Serbia were subject to various physical and chemical analyses; however, Lithol red was not detected on any of them. This pigment has not been revealed until now on the pallets of European painters, but it is commonly found on paintings by the American painter Mark Rothko. Also, ascertained changes of color due to exposure to light in his paintings were noticed. A review of the literature indicated that Lithol red is not only very sensitive to light but is also chemically unstable and sensitive to heat, which makes the painting additionally subject to environmental conditions and mechanical damage. In the largest collection of paintings by one of the most important representatives of Yugoslav modern art, Lazar Vozarević, only a single painting, "Untitled", had a specific type of damage that was not present on any other painting, despite them being kept under the same conditions. Therefore, by precisely determining the composition of the paint layers, it was possible to examine the conservation problem of the artwork, to discover the potential causes of the occurrence of various degradation processes in the future, and to prevent them in a timely manner by applying appropriate measures of preventive conservation. From the aspect of art history, this work contributes to a more accurate positioning of Lazar Vozarevićs painting opus in the context of international artistic trends. This period, both in Yugoslavia and abroad, is characterized by the use of non-painting materials and techniques in the creation of paintings, and therefore, these works are more prone to decay than traditional ones. Characterization of materials that were used to create informal paintings of the 20th century, and which today make significant parts of collections around the world, would allow their durability in the future.

Supplementary Materials: The following are available online at http://www.mdpi.com/2571-9408/2/3/160/s1, Figure S1: Raman spectra of white/grey part of sample 1 for the painting "Untitled" under $532 \mathrm{~nm}$ excitation. Bands at ca. 330, 435, and $1154 \mathrm{~cm}^{-1}$ belong to ZnO. Bands at ca. 1345 and $1585 \mathrm{~cm}^{-1}$ are ascribed to carbon black, Figure S2: Raman spectra of white part of sample 2 for the painting "Untitled" under $632 \mathrm{~nm}$ excitation. Band at ca. $989 \mathrm{~cm}^{-1}$ belongs to $\mathrm{BaSO}_{4}$. Band at ca. $1089 \mathrm{~cm}^{-1}$ is ascribed to $\mathrm{CaCO}_{3}$, Table S1: Characteristic Raman peaks and corresponding references used for the assignment [32-45].

Author Contributions: Conceptualization, V.J., P.C. and A.K.; methodology, P.C., S.E. and A.K.; software, P.C., S.E. and A.K.; validation, V.J., S.E., P.C. and A.K.; formal analysis, V.J., S.E., P.C. and A.K.; investigation, V.J., S.E., P.C. and A.K.; resources, V.J., S.E., P.C. and A.K.; data curation, V.J., S.E., P.C. and A.K.; writing-original draft preparation, V.J., S.E., P.C. and A.K.; writing-review and editing, V.J., S.E., P.C. and A.K.; visualization, V.J., S.E., P.C. and A.K.; supervision, P.C. and A.K.; project administration, V.J.; funding acquisition, V.J., S.E., P.C. and A.K.

Funding: The Serbian Ministry of Education and Science has financially supported this work under contracts OI 176016 and III 45015. 
Acknowledgments: We would like to thank Jonjaua Ranogajec and the team of the Laboratory for Examination of Materials in Cultural Heritage from Technological Faculty, University of Novi Sad (Serbia) as well as Mirjana Cvetkovic from Institute of Chemistry, Technology and Metallurgy, The Department of Chemistry, for the preformed analysis and consultations, Marko Aleksic, Ayako Studio, Belgrade (Serbia), for interesting discussions, insights and explanation about virtual restoration, Ognjen Kovacevic from CIK for the characteristics of the 'Art Informel' phase of Lazara Vozarević as well as the selection of significant biographical data of the painter. We thank Filip Stojic for language polishing and for comments that greatly improved the manuscript.

Conflicts of Interest: The authors declare no conflict of interest. The funders had no role in the design of the study; in the collection, analyses, or interpretation of data; in the writing of the manuscript, or in the decision to publish the results.

\section{References}

1. Vandenabeele, P.; Edwards, H.G.M.; Moens, L. A Decade of Raman Spectroscopy in Art and Archaeology. Chem. Rev. 2007, 107, 675-686. [CrossRef] [PubMed]

2. Lee, A.S.; Otieno-Alego, V.; Creagh, D.C. Identification of iron-gall inks with near-infrared Raman microspectroscopy. J. Raman Spectrosc. 2008, 39, 1079-1084. [CrossRef]

3. Baraldi, P.; Baraldi, C.; Curina, R.; Tassi, L.; Zannini, P. A micro-Raman archaeometric approach to Roman wall paintings. Vib. Spectrosc. 2007, 43, 420-426. [CrossRef]

4. Stanzani, E.; Bersani, D.; Lottici, P.P.; Colomban, P. Analysis of artist's palette on a 16th century wood panel painting by portable and laboratory Raman instruments. Vib. Spectrosc. 2016, 85, 62-70. [CrossRef]

5. Trentelman, K.; Turner, N. Investigation of the painting materials and techniques of the late-15th century manuscript illuminator Jean Bourdichon. J. Raman Spectrosc. 2009, 40, 577-584. [CrossRef]

6. Edwards, H.G.M.; Farwell, D.W. The conservational heritage of wall paintings and buildings: An FT-Raman spectroscopic study of prehistoric, Roman, mediaeval and Renaissance lime substrates and mortars. J. Raman Spectrosc. 2008, 39, 985-992. [CrossRef]

7. Vandenabeele, P.; De Paepe, P.; Moens, L. Study of the 19th century porcelain cards with direct Raman analysis. J. Raman Spectrosc. 2008, 39, 1099-1103. [CrossRef]

8. Goodall, R.A.; Hall, J.; Viel, R.; Agurcia, F.R.; Edwards, H.G.M.; Fredericks, P.M. Raman microscopic investigation of paint samples from the Rosalila building, Copan, Honduras. J. Raman Spectrosc. 2006, 37, 1072-1077. [CrossRef]

9. Kokkori, M.; Hubert, M.-O.; Balcar, N.; Barabant, G.; Sutherland, K.; Casadio, F. Gloss paints in late paintings by Francis Picabia: A multi-analytical study. Appl. Phys. 2016, 122, 11. [CrossRef]

10. Casadio, M.; Bezúr, A.; Fiedler, I.; Muir, K.; Trad, T.; Maccagnola, S. Pablo Picasso to Jasper Johns: A Raman study of cobalt-based synthetic inorganic pigments. J. Raman Spectrosc. 2012, 43, 1761-1771. [CrossRef]

11. Ropret, P.; Centeno, S.A.; Bukovec, P. Raman identification of yellow synthetic organic pigments in modern and contemporary paintings: Reference spectra and case studies. Spectrochim. Acta Part A 2008, 69, 486-497. [CrossRef]

12. Scherrer, N.C.; Zumbuehl, S.; Delavy, F.; Fritsch, A.; Kuehnen, R. Synthetic organic pigments of the 20th and 21st century relevant to artist's paints: Raman spectra reference collection. Spectrochim. Acta Part A 2009, 73, 505-524. [CrossRef]

13. Castro, K.; Perez-Alonso, M.; Rodriguez-Laso, M.D.; Fernandez, L.A.; Madariaga, J.M. On-line FT-Raman and dispersive Raman spectra database of artists' materials (e-VISART database). Anal Bioanal. Chem. 2005, 382, 248-258. [CrossRef] [PubMed]

14. Colomban, P. The Destructive/Non-Destructive Identification of Enamelled Pottery, Glass Artefacts and Associated Pigments-A Brief Overview. Arts 2013, 2, 77-110. [CrossRef]

15. Fremout, W.; Saverwyns, S. Identification of synthetic organic pigments: The role of a comprehensive digital Raman spectral library. J. Raman Spectrosc. 2012, 43, 1536-1544. [CrossRef]

16. Sendova, M.; Kaiser, B.; Scalera, M.; Zhelyaskov, V. Della Robbia blue glaze: Micro-Raman temperature study and X-ray fluorescence spectroscopy characterization. J. Raman Spectrosc. 2010, 41, 469-472. [CrossRef]

17. Burgio, L.; Melessanaki, K.; Doulgeridis, M.; Clark, R.J.H.; Anglos, D. Pigment identification in paintings employing laser induced breakdown spectroscopy and Raman microscopy. Spectrochim. Acta Part B 2001, 56, 905-913. [CrossRef] 
18. Merenik, L. Umetnost i Vlast. Srpsko Slikarstvo 1945-1968 [Art and Power. Serbian Painting 1945-1968]; Fond Vujicic: Belgrade, Serbian, 2010; p. 113.

19. Trifunović, L. Od Impesionizma Do Enformela [From Impressionism to Art Informel]; Nolit: Belgrade, Serbian, 1982; p. 85.

20. Stanojević, Đ. Slikanje Lazara Vozarevića Ili Traganje Za Identitetom [Lazara Vozarević's Painting or Identity Search] Živopis 7; The Academy of the Serbian Orthodox Church for Arts and Conservation: Belgrade, Serbia, 2013; p. 179.

21. Vandenabeele, P.; Moens, L.; Edwards HG, M.; Dams, R. Raman spectroscopic database of azo pigments and application to modern art studies. J. Raman Spectrosc. 2000, 31, 509-517. [CrossRef]

22. Maquoi, M.-C.; Fremout, W. KIK IRPA SOP Spectral Library. 2010. Available online: https://soprano.kikirpa. be/index.php?lib=sop\&id=PR49_1_A_785_kikirpa (accessed on 7 December 2019).

23. Standeven, H.A.L. The History and Manufacture of Lithol Red, a Pigment Used by Mark Rothko in his Seagram and Harvard Murals of the 1950s and 1960s. Tate Pap. 2008, 10, 1-8.

24. Živković, V.; Džikić, V. Return to basics-Environmental management for museum collections and historic houses. Energy Build. 2015, 95, 116-123. [CrossRef]

25. Džikić, V.; Ćosic, N. Препоруке за обезбеђивањеадекватних услова чувања фонда у депоуГалерије ЛазарВозаревић уСремској Митровици[Recommendations for providing adequate conditions for keeping the fund in the depot of the Lazar Vozarević Gallery in Sremska Mitrovica]. Unpublished report. 2013.

26. Jovanović, V. The Conservation of Petar Lubarda's Painting Prisoner-Challenges and Results, Public paintings by Edvard Munch and his contemporaries. In Change and Conservation Challenges, Proceedings International Conference in Oslo; Frysaker, T., Ed.; Archetype Publications: London, UK, 2012; pp. 325-333.

27. Roberts, C. 2009. Available online: http://carolineroberts.blogspot.com/2009/01/toxicity-of-pigments.html (accessed on 7 December 2019).

28. Stenger, J.; Khandekar, N.; Raskar, R.; Cuellar, S.; Mohan, A.; Gschwind, R. Conservation of a room: A treatment proposal for Mark Rothko's Harvard Murals. Stud. Conserv. 2016, 61, 348-361. [CrossRef]

29. Stenger, J.; Kwan, E.E.; Eremin, K.; Speakman, S.; Kirby, D.; Stewart, H.; Huang, S.G.; Kennedy, A.R.; Newman, R.; Khandekar, N. Lithol red salts: Characterization and deterioration. E-Preserv. Sci. 2010, 7, 147-157.

30. Janke, M.; Riedl, N. Missing piece of 16th-century mural recreated virtually. The Art Newspaper, 4 November 2010.

31. Aleksic, M.; Jovanovic, V. Painting Restoration in Improved Reality. Communications in Computer and Information Science 904. In Proceedings of the 1st International Conference on VR Technologies in Cultural Heritage, Brasov, Romania, 29-30 May 2018; pp. 206-214.

32. Culka, A.; Jehlička, J. Raman microspectrometric investigation of urea in calcite and gypsum powder matrices. J. Raman Spectrosc. 2010, 41, 1743-1747. [CrossRef]

33. Baraldi, P.; Fagnano, C.; Bensi, P. Raman study of a «Tabula Colorum Physiologica» in a 1686 printed journal. J. Raman Spectrosc. 2006, 37, 1104-1110. [CrossRef]

34. Bell, I.M.; Clark, R.J.H.; Gibbs, P.J. Raman spectroscopic library of natural and synthetic pigments (pre- 1850 AD). Spectrochim. Acta Part A 1997, 53, 2159-2179. [CrossRef]

35. Benquerenca, M.-J.; Mendes, N.F.C.; Castelluci, E.; Gaspar, V.M.F.; Gil, F.P.S.C. Micro-Raman spectroscopy analysis of 16th century Portuguese Ferreirim Masters oil paintings. J. Raman Spectrosc. 2009, 40, 2135-2143. [CrossRef]

36. Edwards, H.G.M.; Chalmers, J.M. Raman Spectroscopy in Archaeology and Art History. RSC Anal. Spectrosc. Monogr. 2005, 740, 192-206.

37. Kaminska, A.M.; Sawczak, M.; Ouija, M.; Domingo, C.; Castillejo, M.; Sliwinski, G. Pigment identification of a XIV/XV c. wooden crucifix by means of the Raman spectroscopic technique. J. Raman Spectrosc. 2006, 37, 1125-1130. [CrossRef]

38. Correia, A.M.; Clark, R.J.H.; Ribeiro, M.I.M.; Duarte, M.L.T.S. Pigment study by Raman microscopy of 23 paintings by the Portuguese artist Henrique Pousão (1859-1884). J. Raman Spectrosc. 2007, 38, 1390-1405. [CrossRef]

39. Baroni, S. Restaurationet Conservation des Tableaux Manuel Pratique; Celiv: Paris, France, 1993. 
40. Burgio, L.; Clark, R.J.H. Library of FT-Raman spectra of pigments, minerals, pigment media and varnishes, and supplement to existing library of Raman spectra of pigments with visible excitation. Spectrochim. Acta Part A 2001, 57, 1491-1521. [CrossRef]

41. Griffith, W.P. Raman Spectroscopy of Terrestrial Minerals, in Infrared and Raman Spectroscopy of Lunar and Terrestrial Minerals; Academic Press Inc.: Cambridge, MA, USA, 1975; pp. 299-323.

42. Andrikopoulos, K.S.; Danillia, S.; Roussel, B.; Janssens, K. In vitro validation of a mobile Raman-XRF micro-analytical instrument's capabilities on the diagnosis of Byzantine icons. J. Raman Spectrosc. 2006, 37, 1026-1034. [CrossRef]

43. Schulte, F.; Brzezinka, K.-W.; Lutzenberger, K.; Stege, H.; Panne, U. Raman spectroscopy of synthetic organic pigments used in 20th century works of art. J. Raman Spectrosc. 2008, 39, 1455-1463. [CrossRef]

44. Lafuente, B.; Downs, R.T.; Yang, H.; Stone, N. The power of databases: The RRUFF project. In Highlights in Mineralogical Crystallography; Armbruster, T., Danisi, R.M., Eds.; W. De Gruyter: Berlin, Germany, 2015; pp. 1-30.

45. Froment, F.; Tournie, A.; Colomban, P. Raman identification of natural identification red to yellow pigments: Ochre and iron-containing ores. J. Raman Spectrosc. 2008, 39, 560-568. [CrossRef]

(C) 2019 by the authors. Licensee MDPI, Basel, Switzerland. This article is an open access article distributed under the terms and conditions of the Creative Commons Attribution (CC BY) license (http://creativecommons.org/licenses/by/4.0/). 